\title{
EDUCATION AND HEALTHCARE AT RISK FOR CHILDREN IN AFGHANISTAN
}

KABUL, 18 April 2016 - Children in Afghanistan increasingly struggle to access healthcare and education, the UN said in the report released today, 'Education and Healthcare at Risk - Key trends and incidents affecting children's access to healthcare and education in Afghanistan.'

Jointly produced by the United Nations Assistance Mission in Afghanistan (UNAMA) and UNICEF, the report documents how conflict-related violence, threats and intimidation by all parties to the conflict harmed health and education personnel, reduced the availability of healthcare, and limited children's access to essential health and education services. The report covers the three-year period, 1 January 2013 to 31 December 2015.

"The report's findings are deeply troubling. It is simply unacceptable for teachers, doctors and nurses to be subjected to violence or threats, and for schools and medical facilities to be misused or attacked," said Nicholas Haysom, the UN Secretary-General's Special Representative for Afghanistan, "All parties must take measures to protect education and health services in Afghanistan."

In 2015 UNAMA and UNICEF documented 125 incidents affecting access to healthcare, compared to 59 in 2014, including 20 health workers killed, 43 injured and 66 abducted. 132 conflict-related incidents affecting access to education and education-related personnel were also documented, including 11 education personnel killed, 15 injured and 49 abducted. This was a sharp increase over 2014 figures.

Of the 257 incidents documented in 2015, the majority comprised of threats and intimidation, an increase of 182 per cent compared to 2014. Acts of threats and intimidation included: death threats; assaults of health and education personnel; forced closures of schools; letters prohibiting school attendance, particularly against girls; extortion and other harmful acts. UNAMA and UNICEF also documented incidents of improvised explosive devices detonated near schools and clinics, killing and injuring healthcare and education personnel.

"In 2015 children increasingly struggled to access health and education services in Afghanistan due to insecurity and conflict-related violence, further exacerbated by high levels of chronic poverty throughout the country," said Akhil lyer, UNICEF Representative in Afghanistan.

Conflict-related violence resulted in the partial or complete closure of more than 369 schools in 2015, affecting more than 139,000 students and 600 teachers.

The report highlights the particular vulnerabilities faced by girls, noting attacks, threats and explicit prohibitions imposed to restrict girls' education.

"Conflict-related violence not only puts Afghan children at risk of harm, but also limits their fundamental rights to education and healthcare," said Danielle Bell, UNAMA Human Rights Director. "Efforts must be redoubled to enable children - particularly girls - free and safe access to medical services and education."

The report addresses a number of recommendations to all parties to the conflict so as to enable children's unimpeded access to education and healthcare.

\section{United Nations Assistance Mission in Afghanistan (UNAMA), Kabul, Afghanistan}

For more information, please contact: Spokesperson-UNAMA@un.org

UNAMA online: http://unama.unmissions.org • Facebook • Twitter • Flickr • YouTube 